\title{
PENGARUH MODEL PEMBELAJARAN FSLC TERHADAP KEMAMPUAN PEMECAHAN MASALAH MATEMATIKA DITINJAU DARI MOTIVASI BELAJAR SISWA
}

\author{
Komariya $^{1)}$, Nurul Farida ${ }^{2)}$, Ira Vahlia ${ }^{3)}$ \\ 1)2)3) Universitas Muhammadiyah Metro \\ E-mail: komariyahd22@gmail.com ${ }^{1)}$,nurulfaridamath@gmail.com ${ }^{2)}$, \\ iravahlia768@yahoo.co.id ${ }^{3)}$
}

\begin{abstract}
This study aims to decide the effect of learning models on the ability to solve mathematical problems seen from student learning motivation. Learning model used is FSLC and conventional learning model. This type of research is a quasi experiment. The population in this research is the students of class VIII SMP N 1 Trimurjo academic year 2017/2018. The sample of this research is taken by using cluster random sampling technique with sample in experiment class as much as 32, and control class counted 31. The result of this research are as follows: 1) There is difference of problem solving ability between student learning by using FSLC learning model and model of learning conventional. 2) Problem-solving abilities in highly motivated students are better than those with moderate motivation and problem-solving skills in better-motivated students than low motivated students. 3) There is no interaction between FSLC and conventional learning model and learning motivation toward math problem solving ability. The FSLC learning model provides better mathematical problem-solving skills than conventional learning models in both high and medium motivations.
\end{abstract}

Keywords: FSLC learning model, learning motivation, math problem solving skills.

\section{PENDAHULUAN}

Matematika merupakan mata pelajaran yang bukan hanya menitikberat-kan pada persoalan rumus dan perhitungan namun juga perlu ketelitian dan ketrampilan dalam menyelesaikan suatu permasalahan. Permendiknas No.22 Tahun 2006 yang menjelaskan bahwa pelajaran matematika bertujuan agar siswa mampu memecahkan masalah yang meliputi kemampuan memahami masalah, merancang model matematika, menyele-saikan model dan menafsirkan solusi yang diperoleh. Hal ini mengisyaratkan bahwa pembelajaran matematika tidak hanya berorientasi pada peningkatan hasil belajar siswa, tetapi juga harus berorientasi pada peningkatan kemampuan pemecahan masalah.

Kenyataan dilapangan belum sesuai dengan yang diharapkan, seperti yang ditemui di SMP Negeri 1 Trimurjo bahwa kemampuan pemecahan masalah matematika yang dimiliki siswa masih rendah, hal ini ditunjukkan dari 32 siswa hanya $25 \%$ siswa mampu memahami permasalahan, $37,5 \%$ siswa mampu merencanakan penyelesaian, $31,25 \%$ mampu menyelesaikan permasalahan dan 15,62 mampu mengecek kembali.

Rendahnya dari kemampuan pemecahan masalah matematika berkaitan dengan kemampuan siswa dalam menghadapi sebuah soal yang tidak rutin atau soal yang tidak bisa langsung diperoleh solusinya melainkan harus melalui beberapa tahapan. Agustina dan Vahlia (2016) menyatakan bahwa masalah merupakan rangkaian tindakan yang digunakan untuk menyelesaikan masalah dalam mencapai tujuan pembelajaran sehingga dapat membantu mengatasi masalah yang sedang dihadapi mahasiswa. Oleh karena itu, siswa harus memiliki 
kemampuan pemecahan masalah. Anisa (2014) menyatakan bahwa "Kemampuan pemecahan masalah sangat terkait dengan kemampuan siswa dalam membaca dan memahami bahasa soal cerita, menyajikan dalam model matematika, merencanakan perhitungan dari model matematika, serta menyelesaikan perhitungan dari soalsoal yang tidak rutin".

Oleh karena itu diperlukan model pembelajaran yang dapat meningkatkan kemampuan pemecahan masalah, salah satunya yaitu model pembelajaran FSLC (Formulate Share Listen Create). Dimana menurut Afrilianto (2014) terdapat beberapa tahapan dalam model pembelajaran FSLC diantaranya yaitu: formulate yang merupakan kegiatan mencatat informasi yang berkaitan dengan tugas dan membuat rencana penyelesaian, share yaitu siswa berbagi pendapat dengan pasangannya, listen yaitu tiap pasangan saling mendengar pendapat pasangan lainnya, dan mencatat perbedaan dan persamaan pendapat serta create yaitu siswa berdiskusi untuk mencapai kesimpulan.

Terdapat beberapa faktor penyebab kesalahan siswa dalam menyelesaikan soal/ permasalahan yang diberikan, salah satunya yaitu siswa tidak memahami maksud dari soal yang diberikan. Farida dan Agustina (2015) menyimpulkan bahwa siswa salah mengubah informasi yang diberikan ke dalam ungkapan matematika karena siswa tidak memperhatikan maksud soal. Oleh karena itu, melalui model pembelajaran FSLC ini yang lebih tepatnya pada tahap formulate siswa akan dilatih untuk dapat memahami permasalahan sehingga ketika dihadapkan pada sebuah permasalahan, mereka sudah terbiasa dan dapat menyelesaikannya. Selain itu juga model ini memiliki kelebihan, diantaranya yaitu pada fleksibilitasnya, karena semua materi pelajaran bisa menggunakan pembelajaran ini dan berbagai jenis persoalan pun dapat digunakan sebagai bahan diskusi termasuk masalah terbuka, Sulistiana (2017).

Kemampuan pemecahan masalah siswa juga dipengaruhi oleh beberapa faktor diantaranya yaitu motivasi belajar. Melalui motivasi, akan membangkitkan semangat siswa untuk belajar dan dapat mempengaruhi seseorang dalam proses pembelajaran. Berdasarkan hasil wawancara dengan guru matematika SMP Negeri 1 Trimurjo, diketahui bahwa rata-rata siswanya mempunyai motivasi belajar yang masih rendah. Hal ini dapat dilihat dari banyaknya siswa yang tidak mau memperhatikan penjelasan guru saat proses pembelajaran. Selain itu, ketika diberikan tugas hanya beberapa siswa saja yang mau mengerjakan dan ketika diberikan kesempatan untuk bertanya pun hanya ada satu atau dua orang saja yang bertanya. Sebaliknya, ketika seorang siswa memiliki motivasi belajar yang tinggi dia akan berusaha untuk menyelesaikan suatu permasalahan dengan berbagai cara, misalnya dengan membaca referensi atau dengan diskusi bersama teman. Dimana menurut Hamdu (2011) terdapat beberapa indikator motivasi belajar diantaranya yaitu: 1) Durasi kegiatan, 2) Frekuensi kegiatan, 3) Presistensinya pada tujuan kegiatan, 4) Ketabahan, keuletan dan kemampuannya dalam menghadapi kegiatan dan kesulitan untuk mencapai tujuan, 5) Pengabdian dan pengorbanan untuk mencapai tujuan, 6) Tingkatan aspirasi yang hendak dicapai dengan kegiatan yang dilakukan, 7) Tingkat kualifikasi prestasi, 8) Arah sikapnya terhadap sasaran kegiatan. Melalui model pembelajaran FSLC ini diperkirakan dapat mendorong motivasi belajar siswa sehingga siswa menjadi 
aktif, mampu dan berani mengemukakan ide atau rencana penyelesaian dan menjelaskannya kepada temannya serta dapat bertukar pikiran untuk menyelesaikan suatu masalah sehingga dapat membuat penyelesaian dari permasalahan yang dihadapi.

Penelitian ini mempunyai tujuan untuk mengetahui: (1) apakah terdapat perbedaan kemampuan pemecahan masalah atau tidak antara siswa yang belajar dengan menggunakan model pembelajaran FSLC dan model pembelajaran konvensional, (2) kemampuan pemecahan masalah yang lebih baik antara siswa yang memiliki motivasi tinggi, sedang dan rendah, (3) terdapat interaksi atau tidak antara model pembelajaran dan motivasi belajar terhadap kemampuan pemecahan masalah matematika siswa yakni manakah yang memberikan kemampuan pemecahan masalah yang lebih baik antara model pembelajaran FSLC atau pembelajaran konvensional baik pada motivasi belajar yang tinggi, sedang maupun rendah.

\section{METODE PENELITIAN}

Penelitian ini dilaksanakan di SMP Negeri 1 Trimurjo pada semester genap tahun pelajaran 2017/2018. Jenis penelitian ini adalah penelitian eksperimen semu (quasi eksperimental research). Populasi dalam penelitian ini adalah siswa SMP Kelas VIII semester genap tahun pelajaran 2017/2018. Sampling dalam penelitian ini menggunakan teknik cluster random sampling sehingga terpilih sampel sebagai kelas eksperimen yaitu kelas VIII.3, kelas kontrol yaitu kelas VIII.5.
Metode pengumpulan data penelitian meliputi metode tes dan angket. Metode tes digunakan untuk memperoleh data kemampuan pemecahan masalah matematika siswa. Metode angket digunakan untuk memperoleh data motivasi belajar siswa. Sebelum melakukan penelitian, dilakukan uji keseimbangan terhadap kemampuan awal matematika menggunakan uji-t Data kemampuan pemecahan masalah matematika dianalisis menggunakan analisis variansi dua jalan dengan sel tak sama. Sebelumnya, pada data kemampuan awal maupun data kemampuan pemecahan masalah dilakukan uji prasyarat meliputi uji normalitas populasi menggunakan metode Lilliefors dan uji homogenitas variansi populasi menggunakan metode Bartlett. Uji hipotesis menggunakan analisis variansi dua jalan dengan sel tak sama. Apabila hasil analisis variansi menunjukkan bahwa hipotesis nol ditolak, dilakukan uji komparasi ganda menggunakan metode Scheffe. (Budiyono, 2013).

\section{HASIL PENELITIAN DAN PEMBAHASAN}

Hasil uji prasyarat menyimpulkan bahwa semua sampel berasal dari populasi yang berdistribusi normal dan populasi-populasi yang mempunyai variansi yang sama (homogen). Hasil uji keseimbangan diperoleh simpulan bahwa populasi mempunyai kemampuan pemecahan masalah awal yang seimbang. Pengujian hipotesis juga melibatkan interaksi antar masingmasing model pembelajaran dan motivasi. Deskripsi data hasil penelitian di sajikan pada Tabel 1 berikut: 
ISSN 2089-8703 (Print) Vol. 7, No. 1 (2018)

ISSN 2442-5419 (Online)

Tabel 1. Rangkuman Hasil Tes Kemampuan Pemecahan Masalah

\begin{tabular}{|c|c|c|c|c|}
\hline \multirow{3}{*}{ Kelas } & & \multicolumn{3}{|c|}{ Motivasi Belajar } \\
\cline { 2 - 5 } & & Tinggi & Sedang & Rendah \\
\hline \multirow{4}{*}{ FSLC } & $\mathrm{n}$ & 9 & 14 & 9 \\
\cline { 2 - 5 } & $\sum \mathrm{X}$ & 705,00 & 982,00 & 558,00 \\
\cline { 2 - 5 } & $\overline{\mathrm{X}}$ & 78,33 & 70,14 & 62,00 \\
\cline { 2 - 5 } & $\sum \mathrm{X}^{2}$ & 56899,00 & 70262,00 & 35824,00 \\
\cline { 2 - 5 } & $\mathrm{C}$ & 55225,00 & 68880,29 & 34596,00 \\
\cline { 2 - 5 } & $\mathrm{SS}$ & 1674,00 & 1381,71 & 1228,00 \\
\hline \multirow{5}{*}{ Konvensional } & $\mathrm{N}$ & 9 & 11 & 11 \\
\cline { 2 - 5 } & $\sum \mathrm{X}$ & 627,00 & 667,00 & 571,00 \\
\cline { 2 - 5 } & $\overline{\mathrm{x}}$ & 69,67 & 60,64 & 51,91 \\
\cline { 2 - 5 } & $\sum \mathrm{X}^{2}$ & 44663,00 & 41017,00 & 30633,00 \\
\cline { 2 - 5 } & $\mathrm{C}$ & 43681,00 & 40444,45 & 29640,09 \\
\cline { 2 - 5 } & $\mathrm{SS}$ & 982,00 & 572,55 & 992,91 \\
\hline
\end{tabular}

Berdasarkan Tabel 1 dapat diketahui bahwa baik pada motivasi tinggi, sedang maupun rendah, rata-rata kemampuan pemecahan masalah siswa yang belajar dengan menggunakan model pembelajaran FSLC lebih baik

daripada siswa yang belajar dengan menggunakan model konvensional. Rangkuman hasil perhitungan analisis variansi dua jalan dengan sel tak sama disajikan dalam Tabel 2 berikut:

Tabel 2. Rangkuman Hasil Uji Analisis Variansi Dua Jalan Sel Tak Sama

\begin{tabular}{|c|c|c|c|c|c|c|}
\hline Sumber & JK & $\mathrm{dk}$ & $\mathrm{RK}$ & $\mathrm{F}_{\text {hit }}$ & $\mathrm{F}_{\text {tab }}$ & $\begin{array}{c}\text { Kep. } \\
\text { Uji }\end{array}$ \\
\hline $\begin{array}{c}\text { Model } \\
\text { Pembelajaran (A) }\end{array}$ & 1361,890 & 1 & 1361,890 & 11,364 & 4,010 & $\begin{array}{c}\mathrm{H}_{0} \\
\text { ditolak }\end{array}$ \\
\hline $\begin{array}{c}\text { Motivasi Belajar } \\
(\mathrm{B})\end{array}$ & 2972,052 & 2 & 1486,026 & 12,400 & 3,159 & $\begin{array}{c}\mathrm{H}_{0} \\
\text { ditolak }\end{array}$ \\
\hline Interaksi (AB) & 5,243 & 2 & 2,621 & 0,022 & 3,159 & $\begin{array}{c}\mathrm{H}_{0} \\
\text { diterima }\end{array}$ \\
\hline Galat & 6831 & 57 & 119,845 & - & - & \\
\hline Total & 11170,354 & 62 & - & - & - & \\
\hline
\end{tabular}

Berdasarkan Tabel 2, $\mathrm{H}_{0 \mathrm{~A}}$ ditolak berarti terdapat perbedaan kemampuan pemecahan masalah antara siswa yang belajar dengan menggunakan model pembelajaran FSLC dan model konvensional. Hipotesis $\mathrm{H}_{0 \mathrm{~B}}$ ditolak berarti kategori motivasi tinggi, sedang dan rendah memberikan efek yang berbeda terhadap kemampuan pemecahan masalah siswa. Hipotesis $\mathrm{H}_{0 \mathrm{AB}}$ diterima berarti tidak terdapat interaksi antara model pembelajaran dan motivasi belajar terhadap kemampuan pemecahan masala matematika.

Untuk hipotesis $\mathrm{H}_{0}$ ditolak dilakukan uji komparasi ganda. Oleh karena $\mathrm{H}_{0 \mathrm{~A}}$ ditolak akan tetapi karena hanya terdiri dari dua kategori maka tidak perlu dilakukan uji komparasi rerata antar baris, sehingga hanya dilihat dari rerata marginalnya. Hasil rerata marginal menunjukkan bahwa 
kemampuan pemecahan masalah siswa yang belajar menggunakan model pembelajaran FSLC lebih baik daripada siswa yang belajar menggunakan model pembelajaran konvensional. Perbedaan kemampuan pemecahan masalah matematika disebabkan karena adanya perlakuan pada proses pembelajaran. Pembelajaran menggunakan model FSLC pada prinsipnya mendorong siswa untuk lebih memahami suatu masalah hingga menemukan solusi dari pemecahan suatu masalah. Selama proses pembelajaran berlangsung, pembelajaran FSLC mampu mengkoordinasi semua aktivitas siswa, alokasi waktu yang digunakan juga mampu mencakup semua langkahlangkah. Selain itu juga, pembelajaran
FSLC mengharuskan siswa mampu bekerja secara individu sekaligus mampu bekerjasama dan berani mengungkapkan pendapat sehingga pembelajaran FSLC mampu mengembangkan pola pikir siswa, di samping itu siswa juga dapat melatih kerjasama karena dalam model ini siswa juga diharuskan berkelompok.

Safitri (2016) menyimpulkan bahwa kemampuan pemecahan masalah matematika siswa yang mengikuti pembelajaran FSLC lebih baik dari kemampuan pemecahan masalah matematika siswa yang mengikuti pembelajaran konvensional. Oleh karena $\mathrm{H}_{0 \mathrm{~B}}$ ditolak, perlu dilakukan uji komparasi rerata antar kolom.

Tabel 3. Rangkuman Uji Komparasi Antar Kolom

\begin{tabular}{|c|c|c|c|}
\hline $\mathrm{H}_{0}$ & $\mathrm{~F}_{\text {hitung }}$ & $\mathrm{F}_{\text {tabel }}$ & Keputusan \\
\hline $\mathrm{F}_{\cdot 1-\cdot 2}$ & 7,07 & 6,32 & $\mathrm{H}_{0}$ ditolak \\
\hline $\mathrm{F}_{\cdot 2-\cdot 3}$ & 6,78 & 6,32 & $\mathrm{H}_{0}$ ditolak \\
\hline $\mathrm{F}_{\cdot 1-\cdot 3}$ & 24,35 & 6,32 & $\mathrm{H}_{0}$ ditolak \\
\hline
\end{tabular}

Hasil pengujian hipotesis menunjukkan bahwa kemampuan pemecahan masalah matematika siswa yang memiliki motivasi tinggi lebih baik dibandingkan siswa yang memiliki motivasi sedang dan rendah, dan kemampuan pemecahan masalah matematika siswa yang memiliki motivasi sedang lebih baik dibandingkan siswa yang memiliki motivasi rendah. Semakin tinggi motivasi belajar siswa, semakin baik pula kemampuan pemecahan masalah yang diperolehnya. Hal ini dikarenakan motivasi belajar yang tinggi akan memudahkan siswa cepat memahami materi yang diberikan oleh guru, siswa dengan motivasi sedang tidak terlalu sulit dalam menyesuaikan dan memahami materi pelajaran, sedangkan motivasi belajar siswa yang rendah akan membutuhkan proses yang lebih lama dalam memahami materi yang diberikan. Zulaiha (2016) menyimpulkan bahwa kemampuan pemecahan masalah siswa yang mempunyai motivasi tinggi lebih baik daripada siswa dengan motivasi rendah.

Oleh karena $\mathrm{H}_{0 \mathrm{AB}}$ diterima, maka tidak perlu dilakukan uji komparasi rerata antar sel pada kolom yang sama, sehingga hal ini mengikuti efek utama yakni baik pada motivasi tinggi, sedang maupun rendah, model pembelajaran FSLC memberikan kemampuan pemecahan masalah yang lebih baik daripada model konvensional. Hal ini tidak sesuai dengan hipotesis penelitian yang menunjukkan bahwa pada motivasi tinggi dan sedang, baik model FSLC maupun konvensional memberikan kemampuan pemecahan 
masalah yang sama baiknya. Sedangkan pada motivasi belajar rendah, model pembelajaran FSLC memberikan kemampuan pemecahan masalah yang lebih baik daripada model konvensional.

Hal tersebut dikarenakan pada pembelajaran FSLC siswa yang memiliki motivasi tinggi lebih berusaha mencari referensi untuk bisa memahami tentang garis singgung lingkaran pada saat tahap formulate berlangsung, sehingga pada tahap share and listen mereka mampu dan berani mengungkapkan pendapat hingga pada tahap create mereka dapat menciptakan rumus garis singgung lingkaran. Selain itu, pada siswa dengan motivasi sedang, mereka tidak berusaha mencari referensi atau buku bacaan pada saat tahap formulate dan hanya menuliskan apa adanya dari yang mereka ketahui namun pada tahap share and listen hingga tahap create mereka mau berdiskusi dan menanyakan pada teman sekelompok mengenai garis singgung lingkaran. Sedangkan dengan siswa yang memiliki motivasi rendah, walaupun pada tahap formulate mereka tidak mampu untuk menemukan solusi namun pada tahap share and listen mereka mau berdiskusi sehingga mereka menjadi lebih mengerti. Dengan demikian, dengan menggunakan model FSLC baik siswa pada motivasi tinggi, sedang maupun rendah mereka mampu mengingat rumus garis singgung lingkaran dan dapat menyelesaikan permasalahan yang diberikan.

Lain halnya pada pembelajaran konvensional, baik siswa dengan motivasi tinggi, sedang maupun rendah, mereka lebih banyak sebagai penerima sehingga siswa kurang terlibat secara langsung dalam proses pembelajaran. Sedangkan pada model FSLC yang menuntut siswa untuk dapat bekerja secara individu maupun kelompok.

\section{KESIMPULAN DAN SARAN}

Berdasarkan hasil penelitian, dapatdisimpulkansebagaiberikut:

1. Terdapat perbedaan kemampuan pemecahan masalah antara siswa yang belajar dengan menggunakan model pembelajaran FSLC dan model pembelajaran konvensional. Berdasar-kan rerata marginalnya, model pembelajaran FSLC memberikan kemampuan pemecahan masalah yang lebih baik daripada model pembelajaran konvesional.

2. Kemampuan pemecahan masalah pada siswa yang memiliki motivasi tinggi lebih baik daripada siswa yang memiliki motivasi sedang dan rendah serta kemampuan pemecahan masalah pada siswa yang memiliki motivasi sedang lebih baik daripada siswa yang memiliki motivasi rendah.

3. Tidak terdapat interaksi antara model pembelajaran dan motivasi belajar terhadap kemampuan pemecahan masalah matematika siswa. Model pembelajaran FSLC memberikan kemampuan pemecahan masalah matematika yang lebih baik daripada model pembelajaran konvensional baik pada motivasi tinggi, sedang maupun rendah.

Dari kesimpulan di atas, diharapkan bagi guru dapat memilih model yang tepat dalam pembelajaran. Salah satunya yaitu model pembelajaran FSLC yang dapat dijadikan sebagai alternatif model pembelajaran di dalam kelas yang dapat mengembangkan kemampuan pemecahan masalah matematika siswa. Karena terdapat beberapa tahapan pada model pembelajaran FSLC, sebaiknya guru harus dapat mengatur waktu sebaik mungkin agar pembelajaran dapat berjalan sesuai rencana dan pada tahap formulate sebaiknya guru benar-benar 
mengawasi dan membimbing siswa agar mereka mau berusaha menyelesaikan permasalahan yang diberikan, karena berdasarkan pengalaman peneliti pada tahap ini terdapat siswa yang tidak mau berusaha dan justru hanya mencontek. Selain itu, motivasi belajar yang dimiliki siswa sebaiknya lebih ditingkatkan lagi karena semakin tinggi motivasi yang dimiliki semakin baik pula kemampuan pemecahan masalah matematikanya. Bagi peneliti lain, dapat mengembangkan penelitian pada variabel maupun pokok bahasan matematika yang lain juga dapat dilakukan pada jenjang yang lebih tinggi seperti kelas IX atau tingkat sekolah menengah atas.

\section{DAFTAR PUSTAKA}

Afrilianto, M. 2014. Strategi Formulate Share Listen Create Untuk Mengembangkan Kemampuan Mathematical Problem Posing Siswa SMP. Jurnal STKIP Siliwangi Bandung (online). Vol. 8, No. 1, Hal. 24.

Agustina, R. \& Vahlia, I. 2016. Pengembangan Bahan Ajar Berbasis Masalah Pada Mata Kuliah Matematika Ekonomi Program Studi Pendidikan Matematika. Jurnal Aksioma (Online). Vol. 5, No. 2, Hal. 152.

Anisa, W. N. 2014. Peningkatan Kemampuan Pemecahan Masalah dan Komunikasi Matematik Melalui Pembelajaran Pendidikan Matematika Realistik untuk Siswa SMP Negeri di Kabupaten Garut. Jurnal Pendidikan dan Keguruan Pascasarjana Universitas Terbuka Program. Vol. 1, No. 1. Hal. 133.

Budiyono. 2013. Statistik Untuk Penelitian. Surakarta: UNS Press.
Farida, N. dan Agustina, R. 2015. Analisis Kesalahan Siswa SMP Kelas VIII dalam Menyelesaikan Masalah Soal Cerita Matematika. Aksioma Jurnal Pendidikan Matematika FKIP Univ. Muhammadiyah Metro. Vol. 4,No. 2, Hal. 51.

Hamdu, G., \& Lisa, A. 2011. Pengaruh Motivasi Belajar Siswa Terhadap Pestasi Belajar IPA Di Sekolah Dasar. Jurnal Penelitian Pendidikan Universitas Pendidikan Indonesia. Vol. 12, No. 1, Hal. 83.

Permendiknas, RI No. 22 Tahun 2006. Standar Isi untuk Satuan Pendidikan Dasar dan Menengah. Depdiknas: Jakarta.

Safitri, M. D., dkk. 2016. Pengaruh Model Pembelajaran Kooperatif Tipe Formulate-Share-ListenCreate (FSLC) Terhadap Kemampuan Pemecahan Masalah Matematika Siswa Kelas X sma Negeri 1 Sukasada. Jurnal Pendidikan Matematika Undiksha. Vol. 4, No. 1, Hal. 1.

Sulistiana, dkk. 2017. Kemampuan Penalaran Dan Komunikasi Matematis Dengan Penerapan Model Pembelajaran FSLC (Formulate-Share-listen-create) Pada Materi Aritmatika Sosial. JP3 Universitas Islam Malang. Vol. 7, No. 20. Hal. 25.

Zulaiha, dkk. 2016. Pengaruh Model Problem Based Learning Dan Motivasi Belajar Matematika Terhadap Kemampuan Pemecahan Masalah Matematik. Jurnal Pendidikan dan Pembelajaran (online). Vol. 5, No. 5. Hal. 43. 